\title{
Effects of progesterone pretreatment on the oxytocin receptor concentration and the response to oxytocin during the simulated early luteal phase in the ovariectomized ewe
}

\author{
A. P. Beard and M. G. Hunter \\ AFRC Research Group on Hormones and Farm Animal Reproduction, Faculty of Agricultural and Food \\ Sciences, University of Nottingham, Sutton Bonington Campus, Leicester LE12 5RD, UK
}

\begin{abstract}
A steroid-treated ovariectomized ewe model was used to investigate the role of progesterone pretreatment in the control of functional oxytocin receptor concentrations during the early luteal phase. Ovariectomized ewes $(n=28)$ were injected with oestradiol for 2 days (final injection $=$ day 0 ) with or without progesterone pretreatment (progestagen sponge for 10 days). Ewes were then given high or low concentrations of progesterone combined with high, low or zero concentrations of oestradiol in a pattern known to simulate the early luteal phase profile ( $n=4$ per group). Ewes were given $1 \mu \mathrm{g}$ oxytocin (i.v.) on day 4 and plasma was collected to assay 13,14-dihydro-15-keto PGF $_{2 \alpha}$. The concentration of progesterone and oestradiol administered had no effect on the concentration of 13,14-dihydro-15-keto $\mathrm{PGF}_{2 \alpha}$ following oxytocin administration $(P>0.05)$. However, the group that was not pretreated exhibited a small but significant 13,14-dihydro-15-keto PGF $_{2 \alpha}$ response in comparison with the equivalent pretreated group $(P<0.05)$. In a subsequent study, ewes were divided into groups pretreated and not pretreated with progesterone; both groups were given oestrous concentrations of oestradiol and high concentrations of progesterone and oestradiol together. On day $0,2,3$ or 4 , ewes from each group $(n=3,3$, 4 and 4 , respectively) were given $1 \mu \mathrm{g}$ of oxytocin i.v., and the endometrium was collected to measure the binding of oxytocin receptors. Oxytocin caused a significant $(P<0.05)$ increase in the concentration of 13,14-dihydro-15-keto $\mathrm{PGF}_{2 \alpha}$ in all ewes on day 0 but not on days 2, 3 or 4 . Oxytocin receptor concentrations were maximal on day 0 and basal by day 4 . The decline in receptor concentrations occurred more rapidly in the progesteronepretreated than in the ewes that were not pretreated. This study has shown that progesterone pretreatment alters the subsequent steroid hormone control of oxytocin receptor concentrations, and has identified the delayed decline in oxytocin receptor concentrations as the potential cause of premature luteolysis in ewes that are not pretreated.
\end{abstract}

\section{Introduction}

The corpus luteum that develops from the first ovulation following a period of reproductive quiescence (for example seasonal or lactational anoestrus or puberty) is often shortlived, and is correlated with a transient increase in circulating progesterone concentrations (Lamming et al., 1981; Braden et al., 1989; Garverick ef al., 1992). Anoestrous ewes can be induced to ovulate with $\mathrm{GnRH}$, although without progesterone pretreatment a large proportion of the ewes undergo premature luteolysis by the normal luteolytic mechanism (involving prostaglandin $\mathrm{F}_{2 \alpha}\left(\mathrm{PGF}_{2 \alpha}\right)$ from the uterus and oxytocin from the corpus luteum; Hunter et al., 1989). It is proposed that progesterone pretreatment ensures normal luteal function by effects mediated primarily through the uterus rather than the

${ }^{*}$ Correspondence and reprint requests.

Received 7 January 1994. ovary. Hunter (1991) suggested that in GnRH-treated ewes pretreated with progesterone, the rate of decline in the concentration of endometrial oxytocin receptors after oestrus is more rapid than in ewes that are not pretreated. An increased oxytocin receptor concentration in ewes that were not pretreated would allow the premature initiation of the oxytocin$\mathrm{PGF}_{2 \alpha}$ positive feedback loop when the corpus luteum becomes sensitive to $\mathrm{PGF}_{2 \alpha}$ (Hunter et al., 1989). Progesterone pretreatment may play a role in the steroid hormone control of oxytocin receptors early in the luteal phase, possibly by altering steroid hormone receptor concentrations (McCracken et al., 1984; Silvia et al., 1991; Zollers et al., 1993).

The effects of progesterone pretreatment on the oxytocin receptor concentration and the response of 13,14-dihydro-15keto $\mathrm{PGF}_{2 a}$ (PGFM) to oxytocin were initially investigated by Vallet et al. (1990) in ovariectomized ewes. Without progesterone pretreatment the inhibitory effect of progesterone on oxytocin receptors was decreased, while the stimulative effect 
of oestradiol on oxytocin receptors and the PGFM response to oxytocin were increased. However, the steroid hormone administration protocol used by Vallet et al. (1990) did not closely follow the ovarian steroid secretion profile of intact ewes. Progesterone concentrations found during the luteal phase were administered immediately after the 'oestrous' concentration of oestradiol was attained, rather than in a gradually increasing manner. In the present study we treated ovariectomized ewes with a physiological pattern of steroid hormones to determine (I) the effects of oestradiol and progesterone concentrations on the uterine response to oxytocin in ewes that were not pretreated with progesterone, and (2) the patterns of oxytocin receptor concentrations and oxytocin responses during the early luteal phase in both progesteronepretreated ewes and ewes that were not pretreated.

\section{Materials and Methods}

\section{Animals}

Mature Finn-Dorset ewes $(n=28)$ were managed and housed on straw in a well ventilated building under natural conditions of daylength and temperature (May-June). Ewes were fed concentrates and hay throughout the treatment period, with water always available. All ewes were ovariectomized and had previously been treated with exogenous steroid hormones (see Beard $e t$ al., 1994). Ewes were allowed a recovery period of 1 month between studies.

\section{Experiment 1}

Treatments. Ewes were weighed $(48 \pm 1.4 \mathrm{~kg})$ and divided into 7 groups: one pretreated with progesterone $(+P)$ and six were not pretreated $(-P)\langle n=4$ per group). The $+P$ ewes were treated with a progestagen sponge i.v. (fluorogesterone acetate: Chronogest, Intervet UK Ltd, Cambridge) for 10 days. All ewes received 'oestrous' oestradiol injections $(3 \times 16 \mu \mathrm{g}$ in $1 \mathrm{ml} 90 \%$ corn oil day ${ }^{-1}$ ) for 2 days. The time of the last 'oestrous' oestradiol injection was taken as day 0 . The $-P$ ewes were then treated for 4 days with high (maximum of $18 \mathrm{mg} \mathrm{day}^{-1}$ ) or low (maximum of $6 \mathrm{mg}$ day $^{-1}$ ) concentrations of progesterone, combined with high (maximum of $36 \mu \mathrm{g}$ day $^{-1}$ ), low (maximum of $12 \mu \mathrm{g}$ day $^{-1}$ ) or zero concentrations of oestradiol in $\mathrm{I} \mathrm{ml}$ of corn oil, by i.m. injection every $8 \mathrm{~h}$. These steroid treatments were given in the pattern previously described by Beard et al. (1994) to simulate a natural cycle profile: the doses of progesterone were gradually increased, while oestradiol was administered in a wave-like pattern. The $+\mathrm{P}$ ewes were treated with high progesterone and high oestradiol concentrations. On day 4 all ewes were injected i.v. with $1 \mu \mathrm{g}(0.5 \mathrm{iu})$ oxytocin in $1 \mathrm{ml}$ saline.

Collection of blood samples. The jugular vein of all ewes was cannulated 3 days before the last 'oestrous' oestradiol injection. Daily serum and plasma samples were collected mid-way between the morning and afternoon steroid hormone injections for assay of progesterone and oestradiol, respectively. Samples were also taken from each ewe every 1 or $2 \mathrm{~h}$ in the $8 \mathrm{~h}$ before the oxytocin challenge to estimate the steroid hormone concentrations before oxytocin treatment (oestradiol pretreatment and progesterone pretreatment values).

Plasma samples were collected for assay of PGFM every $20 \mathrm{~min}$ in the hour before each oxytocin injection (pretreatment period) and every $10 \mathrm{~min}$ in the following hour (post-treatment period).

Radioimmunoassays. Plasma concentrations of progesterone were measured in $0.1 \mathrm{ml}$ aliquots using the radioimmunoassay described by Haresign et al. (1975) and modified by Hunter et al. (1986). The mean extraction efficiency was $81 \%$, the limit of sensitivity was $0.11 \mathrm{ng} \mathrm{ml}^{-1}$ and the intra-assay coefficient of variation was $14.6 \%$. The interassay coefficient of variation for a reference sample with a concentration of $1.81 \mathrm{ng} \mathrm{m}^{-1}$ was $9.4 \%$ ( $n=7$ assays).

Serum concentrations of oestradiol were determined in $0.25 \mathrm{ml}$ aliquots by a double-antibody radioimmunoassay using a diagnostic kit ( $E_{2}$ MAIA: Serono Diagnostics, Woking) as described by Beard et al. (1994). The mean extraction efficiency was $8.9 \%$; the limit of sensitivity was $0.29 \mathrm{pg} \mathrm{ml}^{-1}$; and the intra-assay coefficient of variation was $12.0 \%$. The interassay coefficients of variation for three samples with concentrations of $3.9,7.3$ and $17.7 \mathrm{pg} \mathrm{ml}^{-1}$ were $17.8,5.1$ and $8.9 \%$, respectively ( $n=4$ assays).

Plasma concentrations of PGFM were measured in $0.5 \mathrm{ml}$ aliquots using the radioimmunoassay described by Kaker $e$ al . (1984). The mean extraction efficiency was $88 \%$; the limit of sensitivity was $32 \mathrm{pg} \mathrm{ml}^{-1}$; and the intra-assay coefficient of variation was $10.8 \%$. The interassay coefficients of variation for two reference samples with a concentration of 121 and $195 \mathrm{pg}$ $\mathrm{ml}^{-1}$ were 13.2 and $13.1 \%$, respectively ( $n=6$ assays).

Statistical analyses. The progesterone, oestradiol and PGFM data were examined by ANOVA; in each set the residuals were normally distributed and the magnitude of the residuals remained approximately constant over the range of values recorded.

Effects of treatment on the oestradiol and progesterone pretreatment values were determined by split-plot ANOVA, with individual sheep used as plots and samples as subplots. Orthogonal contrasts were used to make comparisons of interest between treatment groups (Lowry, 1992).

A PGFM response was defined as an increase in two points during the post-treatment period above the mean $(+2 \mathrm{sDs})$ value of the pretreatment period. Peak height (PGFM peak) was defined as the greatest increase during the post-treatment period above the pretreatment mean.

Effects of treatment on the PGFM post-treatment concentrations were determined by split-plot ANOVA, with individual sheep used as plot and samples as subplots. Differences in treatment means were evaluated by orthogonal contrasts, and patterns of PGFM concentrations were compared using tests of homogeneity of regression over the sampling period.

\section{Experiment 2}

Treatments. Ewes were weighed $(47 \pm 1.5 \mathrm{~kg})$ and assigned to two groups ( $n=14$ per group): progesterone pretreated 
$(+P)$ and not pretreated $(-P)$ groups, both of which were given high progesterone and high oestradiol concentrations (see Beard et al., 1994). The $+P$ ewes received an i.v. progestagen (fluorogesterone acetate) sponge for 10 days. All ewes then received 'oestrous' oestradiol injections for 2 days, followed by treatment for 4 days with high concentrations of progesterone and oestradiol using the same dose regimen and vehicle as for Expt 1 . On days 0, 2, 3 and 4, ewes from each group $(n=3,3,4$ and 4 , respectively) were given $1 \mu \mathrm{g}$ oxytocin i.v., killed within $3 \mathrm{~h}$, and the endometrium collected and processed to measure oxytocin receptor binding.

Collection of blood samples. The jugular veins of all ewes were cannulated on the day before oxytocin administration and plasma samples were collected to assay PGFM, as in Expt 1 .

Radioimmunoassay. Samples were assayed for PGFM as described for Expt 1 . The mean extraction efficiency was $79 \%$; the limit of sensitivity was $36 \mathrm{pg} \mathrm{ml}^{-1}$ and the intra-assay coefficient of variation was $11.6 \%$. The interassay coefficients of variation for two reference samples with concentrations of 150 and $251 \mathrm{pg} \mathrm{ml}^{-1}$ were 6.5 and $4.9 \%$, respectively $(n=5$ assays).

Oxytocin receptor measurements. Concentrations of oxytocin receptors were determined as described by Beard and Lamming (1994). Scintillation counting was carried out with an efficiency of $61 \%$. Nonspecific binding was $0.3 \%$ of the total label used. The limit of sensitivity (calculated as the mean of $2 \times \mathrm{SD}$ from each set of nonspecific binding data was $10.5 \mathrm{fmol}$ oxytocin bound $\mathrm{mg}^{-1}$ protein, and the intra-assay coefficient of variation was $7.0 \%$. The interassay coefficient of variation for a reference oestrous sample was $6.9 \%(n=2$ assays $)$.

Statistical analyses. Effects of treatment and day on the PGFM post-treatment concentration were determined by a $2 \times 4$ factorial ANOVA. Differences in means were evaluated by orthogonal contrasts. A PGFM response and peak height (PGFM peak) were defined as for Expt 1.

The oxytocin receptor data was log-transformed to eliminate heterogeneity of variance among treatment groups before being examined by ANOVA.

\section{Results}

\section{Experiment 1}

Progesterone and oestradiol. Progesterone and oestradiol concentrations in samples taken before and after a steroid hormone injection on day 4 showed that steroid hormone concentrations always remained within physiological limits even immediately after treatment. Analysis of the results of these samples revealed that progesterone concentrations in the groups given high progesterone concentrations were greater than in those given the low progesterone concentrations $(P<0.001)$, and oestradiol concentrations in the groups given high oestradiol concentrations were greater than in those given low oestradiol concentrations $(P<0.001)$. However,

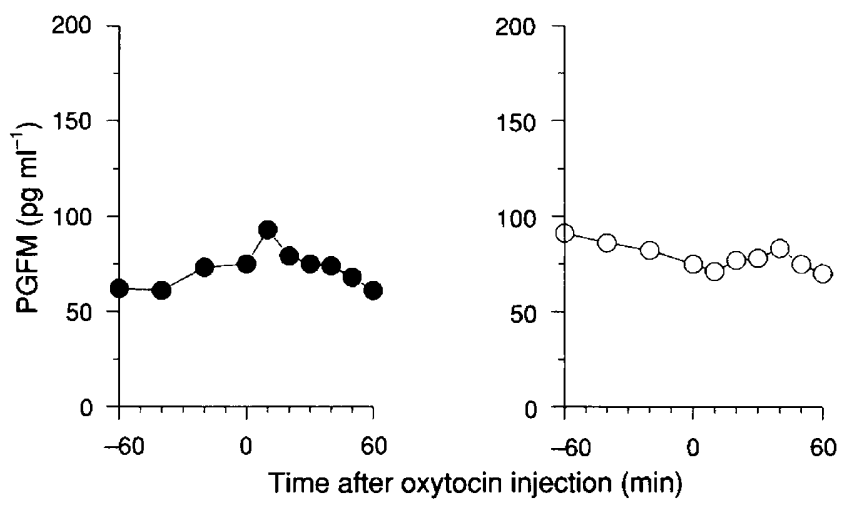

Fig. 1. Mean plasma 13,14-dihydro-15-keto prostaglandin $F_{20}$ $($ PGFM) SED $=10.3$ ) response profiles on day 4 of ewes that were pretreated with progesterone $(O)$ and not pretreated $(O)$ and given high progesterone and high oestradiol concentrations $(n=4)$.

progesterone concentrations $(P>0.05)$ and oestradiol concentrations $(P>0.05)$ did not differ in the $-\mathrm{P}$ and $+\mathrm{P}$ groups given high concentrations of progesterone and oestradiol together. Measurements of progesterone and oestradiol in blood samples taken every day from all ewes showed that hormone concentrations mimicked the temporal changes seen during a natural early luteal phase (data not shown), as described previously by Beard et al. (1994). Progesterone concentrations rose gradually from day 2, while oestradiol concentrations were high during the time when 'oestrous' oestradiol concentrations were given and also during days 2-4 of treatment, which corresponded to the first follicular wave.

PGFM. Analysis of PGFM post-treatment values revealed that the concentration of progesterone or oestradiol (or an interaction between these two) had no effect on the pattern of PGFM release in response to oxytocin $(P>0.05)$. The pattern of the PGFM response was different between $+\mathrm{P}$ and $-\mathrm{P}$ groups given high concentrations of oestradiol and progesterone together $(P<0.05)$, ewes that were not pretreated exhibiting a small increase in PGFM (Fig. 1) after oxytocin administration. However, no ewes in either group showed a defined response to oxytocin.

\section{Experiment 2}

PGFM. The mean PGFM peak values and oxytocin receptor concentrations for $+\mathrm{P}$ and $-\mathrm{P}$ groups are shown in Fig. 2. A PGFM response to the oxytocin injection was obtained in all $+\mathrm{P}$ and $-\mathrm{P}$ ewes on day $\mathrm{O}$ (immediately after the injection of an 'oestrous' oestradiol concentration). However, no response was observed on day 2, 3 or 4 . Progesterone pretreatment had no effect on the pattern of the PGFM response $(P>0.05$; Fig. 3). There was an effect of day on the pattern of PGFM response $(P<0.001)$, although this effect was altered by progesterone pretreatment (day $\times$ treatment interaction; $P<0.01$ ). The pattern of the PGFM response in the $-\mathrm{P}$ and $+\mathrm{P}$ groups given high concentrations of progesterone and oestradiol together on day 4 did not differ $(P>0.05)$. 

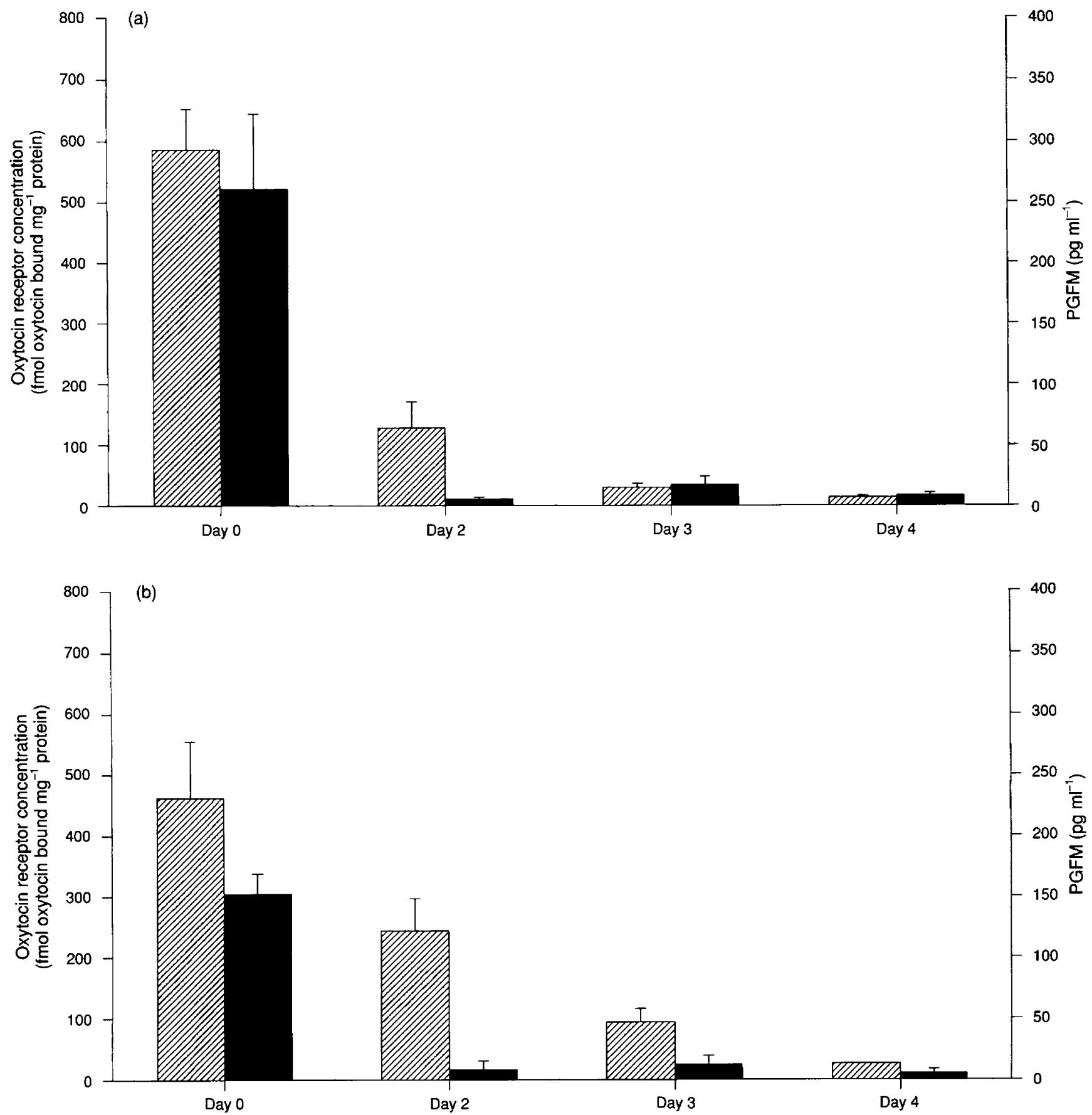

Fig. 2. Mean ( \pm SEM) 13,14-dihydro-15-keto prostaglandin $F_{2 a}$ (PGFM) peak response $(\boldsymbol{\square})$ and uterine oxytocin receptor concentration ( $\square$ ) in (a) progesterone-pretreated ewes and (b) ewes that were not pretreated on days $0,2,3$ and 4 of steroid hormone treatment $(n=3,3,4,4$, respectively).

Uterine oxytocin receptors. Oxytocin receptor concentrations in both $+\mathrm{P}$ and $-\mathrm{P}$ groups were maximal on day $\mathrm{O}$ and declined steadily until day 4 (Fig. 2). Oxytocin receptor concentrations were affected by both progesterone pretreatment and day of measurement, although the effect of day was again altered by pretreatment with progesterone $(P<0.05)$. A more rapid decline in receptor concentrations occurred in $+P$ ewes. Log oxytocin receptor concentrations were positively correlated with PGFM peak values when data from all days were analysed $(P<0.001)$.

\section{Discussion}

The study reported here revealed that progesterone pretreatment causes a rapid decline in uterine oxytocin receptor 


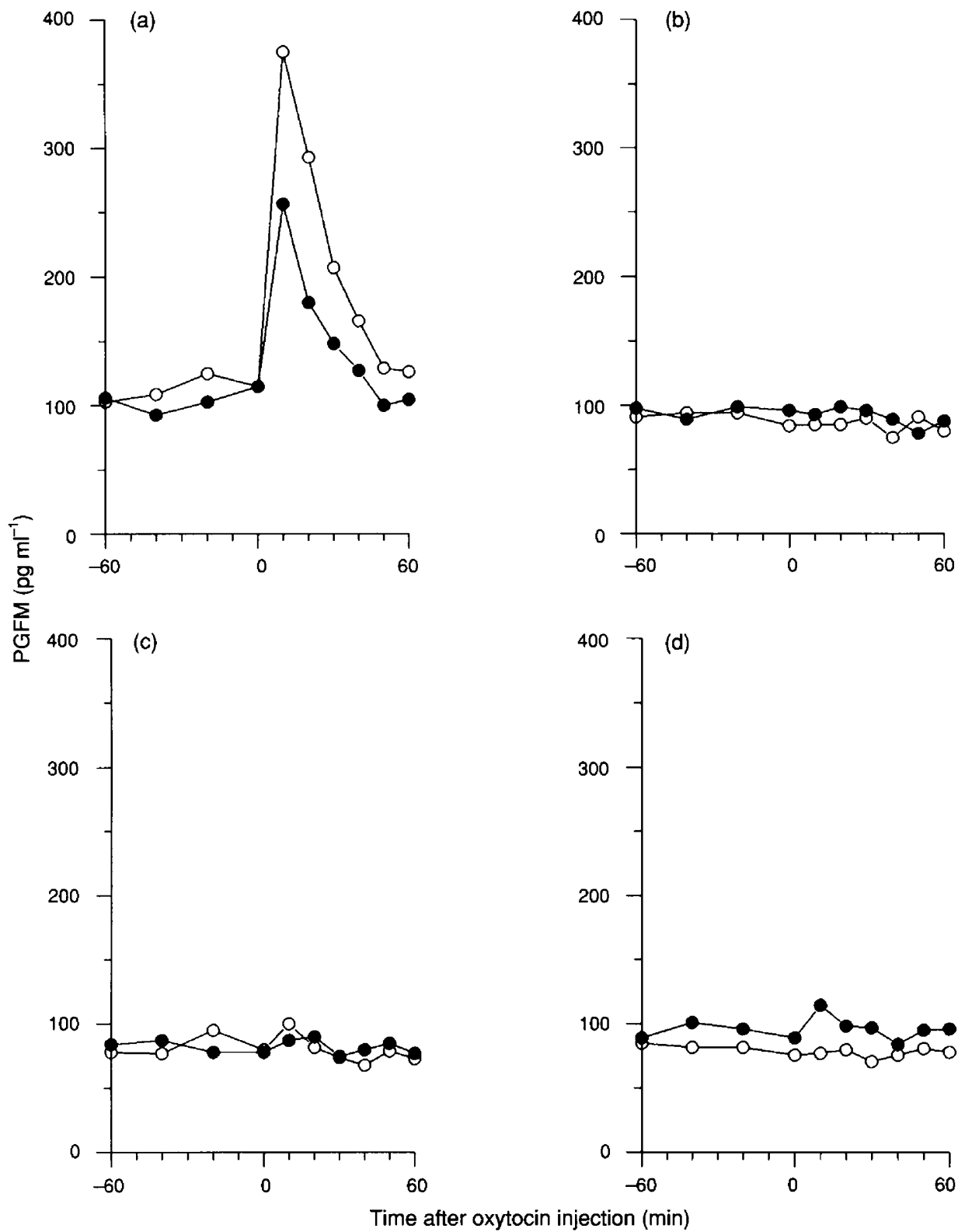

Fig. 3. Mean plasma 13,14-dihydro-15-keto prostaglandin $F_{2 a}(P G F M)$ ( $S E D=28.5$ ) response profiles from progesterone-pretreated ewes $(O)$ and ewes that were not pretreated (O) on days (a) $0,(b) 2$, (c) 3 and (d) 4 of steroid hormone treatment $(n=3,3,4,4$, respectively).

concentrations during the simulated early luteal phase in ovariectomized ewes treated with steroid hormones. The concentration of oxytocin receptors during the luteal phase may be crucial in determining whether the lifespan of the corpus luteum is normal or short-lived.

The delayed decline in oxytocin receptor concentrations in ewes that were not pretreated confirms and extends the work of Vallet et al. (1990), who reported higher concentrations of oxytocin receptors on day 5 of steroid hormone treatment in ovariectomized ewes that were not pretreated compared with pretreated ewes. The present study indicates that the higher concentration on day 5 was due to a slower decrease in oxytocin receptor concentrations from a common high concentration on day 0 . The slower decline in the number of oxytocin receptors associated with premature luteolysis in $\mathrm{GnRH}$-treated ewes that were not pretreated (Hunter, 1991) is in agreement with the delayed decrease measured in the study. Vallet $e t$ al. (1990) stated that a lack of progesterone pretreatment decreases the subsequent inhibitory effect of progesterone that is necessary to prevent luteolysis (Zhang et al., 1992; Lau et al., 1993; Sheldrick and Flick-Smith, 1993). However, an increase in the stimulative effect of endogenous oestradiol (of extraovarian origin) could also mediate these effects (Hixon and Flint, 1987), since approximately $1 \mathrm{pg}$ oestradiol $\mathrm{ml}^{-1}$ is present in the plasma or serum from ovariectomized ewes (Beard et al., 1994; Beard and Lamming, 1994).

Oxytocin receptor concentrations had already declined by day 2 , before exposure to the inhibitory influence of 
progesterone. This confirms the suggestion of Vallet et al. (1990) that the high concentration of oestradiol at oestrus may contribute to the subsequent decrease in oxytocin receptor concentrations. It is speculated that the oestradiol surge at oestrus may downregulate the oestradiol receptor concentration, and prevent full oestrogenic stimulation of oxytocin receptor development. Oestradiol receptor concentrations have been shown to decline after oestrus in ewes (Cherny et al., 1991), before an increase in peripheral progesterone concentrations. Progesterone pretreatment appears to be able to promote the decrease in oestrogenic stimulation, possibly by ensuring that oestradiol receptor concentrations decline rapidly after oestrus and remain reduced. Beard and Hunter (1994) recently demonstrated that the level of oestrogenic stimulation in GnRH-treated ewes that were not pretreated is critical in determining whether the corpus luteum undergoes premature luteolysis or develops normally.

Oxytocin receptor concentrations measured in $-\mathrm{P}$ ewes on days 3 and 4 in the present study are similar to those detected by Hunter et al. (1989) when ewes responded to endogenous pulses of oxytocin (as simultaneous episodes of oxytocin and PGFM were detected in ewes not pretreated with progesterone). Zollers et al. (1989) also reported that postpartum cows that were not pretreated and exhibited subnormal luteal function released $\mathrm{PGF}_{2 \alpha}$ in response to oxytocin during the early luteal phase. Zollers et al. (1993) have since confirmed the presence of high oxytocin receptor concentrations on day 5 in cows that were not pretreated.

A response of PGFM to administered oxytocin was observed in all ewes on day 0 when oxytocin receptor concentrations were high. This is a further example of the response to oxytocin being determined primarily by the oxytocin receptor concentration. Correlations between receptor concentrations and tissue responsiveness have been described in ewes by Sheldrick and Flint (1985) and in cows by Jenner et al. (1991) and Mirando et al. (1993). However, the PGFM response was not apparent on day 2, despite the presence of an intermediate concentration of oxytocin receptors. A similar concentration of receptors was shown to be sufficient to enable oxytocin to evoke a PGFM response at the end of the simulated cycle in a previous experiment (Beard and Lamming, 1994). It is possible that the high 'oestrous' oestradiol concentration may temporarily disrupt the postreceptor mechanism. Measurement of oxytocin receptor concentrations provides information on one aspect of the complex role of steroids in the control of luteolysis. However, postreceptor events, such as steroid interactions in second messenger systems and effects on the enzymes involved in prostaglandin synthesis, are also important (Raw and Silvia, 1991; Silvia and Raw, 1993).

The two experiments in the present study provide conflicting evidence in relation to the effect of progesterone pretreatment on the PGFM response to oxytocin on day 4. A lack of progesterone pretreatment stimulated a small but significant increase in the PGFM concentration following oxytocin administration in Expt 1. However, in Expt 2 the stimulative effect of the absence of progesterone pretreatment was not significant. When Expts 1 and 2 are compared the pattern of PGFM production is found to be more variable in Expt 2, making it more difficult to detect a statistically significant difference. In both experiments the mean increase in PGFM concentration following oxytocin administration in the $-\mathrm{P}$ group was similar, but not substantial, and so no firm conclusions can be drawn. Vallet et al. (1990) detected a slightly larger PGFM response in ewes that were not pretreated with progesterone, which was significantly greater than that seen in pretreated ewes. Differences in steroid hormone treatment regimens (noted above) may explain the apparent contradictory results between this study and that of Vallet et al. (1990).

The PGFM response in ovariectomized ewes treated with steroid hormones but not pretreated with progesterone was not affected by the concentration of steroid hormones administered. This result was unexpected given the known quantitative effects of steroid hormones at the end of the luteal phase in ewes (Beard ef al., 1994) and cows (Silvia and Taylor, 1989; Parkinson and Lamming, 1990). However, the response to oxytocin was measured after only a short exposure to differential progesterone concentrations.

In summary, this study has identified the delayed decline in oxytocin receptor concentrations as the potential cause of premature luteolysis in ewes that were not pretreated. It has demonstrated that progesterone pretreatment enhances the postoestrous decline in the concentration of oxytocin receptors, ensuring that oxytocin receptor concentrations are basal early in the simulated luteal phase (day 4), at a time equivalent to the onset of premature luteolysis. This is achieved by altering the response to subsequent steroid hormones (particularly oestradiol), presumably via effects on progesterone and oestradiol receptor concentrations. Progesterone pretreatment is required for the normal steroid hormone control of oxytocin receptors to be initiated.

A. P. Beard was in receipt of a MAFF postgraduate scholarship. The authors thank the staff of JABU for their help with the animal work and J. Craigon for statistical advice.

\section{References}

Beard AP and Hunter MG (1994) Effects of bovine follicular fluid (bff) and exogenous oestradiol on the GnRH induced short luteal phase in anoestrous ewes Journal of Reproduction and Fertility 100 211-217

Beard AP and Lamming GE (1994) Oestradiol and the development of the uterine oxytocin receptor and the oxytocin-induced $P G_{2 \alpha}$ release in ewes Journal of Reproduction and Fertility 100 469-475

Beard AP, Hunter MG and Lamming GE (1994) Quantitative control of oxytocin induced uterine prostaglandin $\mathrm{F}_{2 \alpha}$ release by progesterone and oestradiol in the ewe Journal of Reproduction and Fertility 100 143-150

Braden TD, King ME, Odde KG and Niswender GD (1989) Development of preovulatory follicles expected to form short-lived corpora lutea in beef cows Journal of Reproduction and Fertility 85 97-104

Cherny RA, Salamonsen LA and Findlay JK (1991) Immunocytochemical localization of oestrogen receptors in the endometrium of the ewe Reproduction Fertility and Development 3 321-33I

Garverick HA, Zollers WG and Smith MF (1992) Mechanisms associated with corpus luteum lifespan in animals having normal or subnormal luteal function Animal Reproduction Science 28 111-124

Haresign W, Foster JP, Haynes NB, Crighton DB and Lamming GE (1975) Progesterone levels following treatment of seasonally anoestrous ewes with synthetic LH-releasing hormone Journal of Reproduction and Fertility $\mathbf{4 3}$ 269-279

Hixon JE and Flint APF (1987) Effects of a luteolytic dose of oestradiol benzoate on uterine oxytocin receptor concentrations, phosphoinositide turnover and PGF $_{2 \alpha}$ secretion in sheep Journal of Reproduction and Fertility 79 457-467 
Hunter MG (1991) Characteristics and causes of the inadequate corpus luteum Journal of Reproduction and Fertility Supplement 43 91-99

Hunter MG, Southee JA, McLeod BJ and Haresign W (1986) Progesterone pretreatment has a direct effect on $\mathrm{GnRH}$-induced preovulatory follicles to determine their ability to develop into normal corpora lutea in anoestrous ewes Journal of Reproduction and Fertility 76 349-363

Hunter MG, Ayad VJ, Gilbert CL, Southee JA and Wathes DC (1989) Role of prostaglandin F-2a and oxytocin in the regression of GnRH-induced abnormal corpora lutea in anoestrous ewes Joumal of Reproduction and Fertility 85 551-561

Jenner LJ, Parkinson TJ and Lamming GE (1991) Uterine oxytocin receptors in cyclic and pregnant cows Journal of Reproduction and Fertility 91 49-58

Kaker ML, Murray RD and Dobson H (1984) Plasma hormone changes in cows during induced or spontaneous calvings and the early post partum period Veterinary Record 115 378-382

Lamming GE, Wathes DC and Peters AR (1981) Endocrine patterns of the post-partum cow Journal of Reproduction and Fertility Supplement 30 155-170

Lau TM, Kerton DJ, Gow CB and Fairclough RJ (1993) Role of progesterone in the control of endometrial oxytocin receptors at luteolysis in sheep Journal of Reproduction and Fertility 98 229-233

Lowry SR (1992) Use and misuse of multiple comparisons in animal experiments Journal of Animal Science 70 1971-1977

McCracken JA, Schramm W and Okulicz WC (1984) Hormone receptor control of pulsatile secretion of $\mathrm{PGF}_{2 \alpha}$ from the ovine uterus during luteolysis and its abrogation in early pregnancy Animal Reproduction Science 7 31-55

Mirando MA, Becker WC and Whiteaker SS (1993) Relationships among endometrial oxytocin receptors, oxytocin-stimulated phosphoinositide hydrolysis and prostaglandin $\mathrm{F}_{2 a}$ secretion in vitro, and plasma concentrations of ovarian steroids before and during corpus luteum regression in cyclic heifers Biology of Reproduction 48 874-882

Parkinson TJ and Lamming GE (1990) Interrelationships between progesterone, 13,14-dihydro-15-keto PGF-2 $\alpha$ (PGFM) and LH in cyclic and early pregnant cows Journal of Reproduction and Fertility 90 221-233
Raw RE and Silvia WJ (1991) Activity of phospholipase C and release of prostaglandin $\mathrm{F}_{2 a}$ by endometrial tissue from ovariectomized ewes receiving progesterone and oestradiol Biology of Reproduction 44 404-412

Sheldrick EL and Flint APF (1985) Endocrine control of uterine oxytocin receptors in the ewe Journal of Endocrinology 106 249-258

Sheldrick EL and Flick-Smith HC (1993) Effect of ovarian hormones on oxytocin receptor concentrations in explants of uterus from ovariectomized ewes Joumal of Reproduction and Fertility $97241-245$

Silvia WJ and Raw RE (1993) Activity of phospholipase C and release of prostaglandin $\mathrm{F}_{2 a}$ by endometrial tissue from ewes during the oestrous cycle and early pregnancy Journal of Reproduction and Fertility $97529-537$

Silvia WJ and Taylor ML (1989) Relationship between uterine secretion of prostaglandin $\mathrm{F}_{2 u}$ induced by oxytocin and endogenous concentrations of oestradiol and progesterone at three stages of the bovine oestrous cycle Journal of Animal Science 67 2347-2353

Silvia WJ, Lewis GS, McCracken JA, Thatcher WW and Wilson L, Jr (1991) Review: Hormonal regulation of uterine secretion of prostaglandin $F_{2 \alpha}$ during luteolysis in ruminants Biology of Reproduction 45 655-663

Vallet JL, Lamming GE and Batten M (1990) Control of endometrial oxytocin receptor and uterine response to oxytocin by progesterone and oestradiol in the ewe Journal of Reproduction and Fertility 90 625-634

Zhang J, Weston PG and Hixon JE (1992) Role of progesterone and oestradiol in the regulation of uterine oxytocin receptors in ewes Journal of Reproduction and Fertility 94 395-404

Zollers WG, Garverick HA and Smith MF (1989) Oxytocin-induced release of prostaglandin $\mathrm{F}_{2 a}$ in postpartum beef cows: comparison of short versus normal luteal phases Biology of Reproduction 41 262-267

Zollers WG, Garverick HA, Smith MF, Moffatt RJ, Salfen BE and Youngquist RS (1993) Concentrations of progesterone and oxytocin receptors in endometrium of postpartum cows expected to have a short or normal oestrous cycle Journal of Reproduction and Fertility 97 329-337 